Research Paper

\title{
Analysis of the In Vivo and In Vitro Effects of Photodynamic Therapy on Breast Cancer by Using a Sensitizer, Sinoporphyrin Sodium
}

\author{
Xiaobing Wang ${ }^{1, *}$, Jianmin $\mathrm{Hu}^{1,}{ }^{,}$, Pan Wang ${ }^{1}$, Shaoliang Zhang ${ }^{2}$, Yichen Liu ${ }^{1}$, Wenli Xiong1, Quanhong \\ $\mathrm{Liu}^{1}{ }^{凶}$ \\ 1. Key Laboratory of Medicinal Resources and Natural Pharmaceutical Chemistry, Ministry of Education, National Engineering Labora- \\ tory for Resource Developing of Endangered Chinese Crude Drugs in Northwest of China, College of Life Sciences, Shaanxi Normal \\ University, Xi'an, Shaanxi, People's Republic of China. \\ 2. Qinglong High-Tech Co., Ltd, Yichun, Jiangxi, People's Republic of China. \\ * The authors contributed equally to this work.
}

$\square$ Corresponding author: Quanhong Liu, Key Laboratory of Medicinal Resources and Natural Pharmaceutical Chemistry, Ministry of Education, National Engineering Laboratory for Resource Developing of Endangered Chinese Crude Drugs in Northwest of China, College of Life Sciences, Shaanxi Normal University, Xi'an 710062, Shaanxi, China. E-mail: Quanhong Liu, lshaof@snnu.edu.cn; Telephone: + 86-29-8531 0275

( 2015 Ivyspring International Publisher. Reproduction is permitted for personal, noncommercial use, provided that the article is in whole, unmodified, and properly cited. See http://ivyspring.com/terms for terms and conditions.

Received: 2014.10.19; Accepted: 2015.03.06; Published: 2015.04.06

\begin{abstract}
Photodynamic therapy (PDT) is an emerging theranostic modality for various cancers and diseases. Photosensitizers are critical components for PDT. Sinoporphyrin sodium, referred to as DVDMS, is a newly identified photosensitizer that was isolated from Photofrin. Here, we evaluated the effects of DVDMS-mediated PDT (DVDMS-PDT) on tumor cell proliferation and metastasis in the highly metastatic 4T1 cell line and a mouse xenograft model. DVDMS-PDT elicited a potent phototoxic effect in vitro, which was abolished using the reactive oxygen species (ROS) scavenger $\mathrm{N}$-acetylcysteine. In addition, DVDMS-PDT effectively inhibited the migration of 4Tl cells in scratch wound-healing and transwell assays. Using an in vivo mouse model, DVDMS-PDT greatly prolonged the survival time of tumor-bearing mice and inhibited tumor growth and lung metastasis, consistent with in vitro findings. PDT with DVDMS had a greater anti-tumor efficacy than clinically used Photofrin. Moreover, preliminary toxicological results indicate that DVDMS is relatively safe. These results suggest that DVDMS is a promising sensitizer that warrants further development for use in cancer treatment with PDT or other sensitizing agent-based therapies.
\end{abstract}

Key words: DVDMS, Photodynamic therapy, Proliferation, Metastasis, 4T1 cells.

\section{Introduction}

Breast cancer is the most commonly diagnosed cancer in women and the second leading cause of cancer-related deaths worldwide [1]. Metastases are the primary cause of mortality in breast cancer patients. In spite of significant advancement in therapeutic options, approximately $30 \%$ of breast cancer patients eventually progress to metastatic disease [2]. In addition, approximately $5 \%$ of patients are diag- nosed with stage IV metastatic breast cancer during the initial diagnosis [3].

Photodynamic therapy (PDT) is an effective treatment modality used for the management of solid tumors. This technique is based on the preferential uptake of photosensitizers by tumor cells followed by their activation using an appropriate wavelength of laser light. This causes the photosensitizers to produce 
activated oxygen species and induces tumor cell death [4-6]. PDT is a safe and minimally invasive therapy that has been clinically applied to numerous types of cancers, including lung, cervical, early esophageal, bladder, and head and neck cancers [7-11].

Photosensitizers are critical components of PDT. An ideal photosensitizer for PDT should possess characteristics such as high chemical stability, water-solubility, high phototoxicity, low dark toxicity, preferential accumulation in the tumor tissue, and rapid clearance in patients [12]. Porphyrins, their derivatives, and porphyrin-inducing drugs are by far the most commonly used photosensitizers in PDT $[5,13]$. One of the earliest clinical porphyrin-based photosensitizers is Photofrin ${ }^{\circledR}(\mathrm{PF})$. It has been approved by the FDA for use as a sensitizer in PDT of cancer and is the most widely used photosensitizer thus far. PF has been approved for clinical use to treat early- and late-stage lung cancer, esophageal cancer, bladder cancer, and early-stage cervical cancer [12]. However, $\mathrm{PF}$ is known to be a mixture of dimers and oligomers of hematoporphyrin in which porphyrin molecules are linked by ether, ester, and $\mathrm{C}-\mathrm{C}$ bonds [12]. Therefore, it would be advantageous to employ a purified and well-defined photosensitizer rather than a complex mixture, which, though effective, is not completely understood. In addition, PF requires a long clearance time (4-8 weeks) to avoid skin photosensitization [12]. Patients are warned to avoid direct skin or eye exposure to sunlight or bright indoor lights for at least 30 days post PF treatment.

The disadvantages of using PF have stimulated efforts to develop more effective photosensitizers. Qicheng Fang and colleagues have performed numerous studies exploring the active portion of PF. They found the fraction that exhibited anti-cancer activity was porphyrin dimer salt connected by an ether bond. It was named Sinoporphyrin sodium, also referred to as DVDMS. DVDMS was granted intellectual property rights in China [14]. In addition, DVDMS-based PDT was evaluated for skin phototoxicity and for growth inhibition in several xenograft tumors [14]. DVDMS inhibits tumor growth to a greater extent than PF and has lower skin phototoxicity than Hiporfin, which was approved by the Chinese State Food and Drug Administration (SFDA) for use in PDT but whose production has been suspended by the manufacturer because of severe adverse effects $[14,15]$. These early results suggested that DVDMS has great potential for use in clinical PDT.

The function of DVDMS in PDT remains poorly understood, with only a patent [14] and two publications $[15,16]$ being available on this aspect. Moreover, DVDMS-PDT has not been investigated in breast cancer models, and there are currently no reports on its role in treating metastasis. Here, we utilized the BALB/c-derived mouse mammary carcinoma cell line 4T1. These cancer cells share numerous characteristics with human mammary carcinoma, including immunogenicity, growth characteristics, and metastatic properties. We focused our investigation on the anti-tumor effects of DVDMS-PDT, examining proliferation and metastasis both in vitro and in vivo. To the best of our knowledge, the present study is the first in vitro and in vivo preclinical study that assesses the anti-metastatic effects of DVDMS-PDT. These findings may have important implications for the treatment of cancer.

\section{Materials and methods}

\section{Sensitizers}

Sinoporphyrin sodium (DVDMS) was kindly provided by Professor Qicheng Fang from the Chinese Academy of Medical Sciences (Beijing, China). It has a purity of $98.5 \%$. It was dissolved in a physiological saline solution to a final storage concentration of $1.25 \mathrm{mg} / \mathrm{ml}$ and was stored in the dark at $-20^{\circ} \mathrm{C}$. The chemical structure of DVDMS is shown in Fig. 1. Photofrin (PF) was a gift from Professor Qicheng Fang.

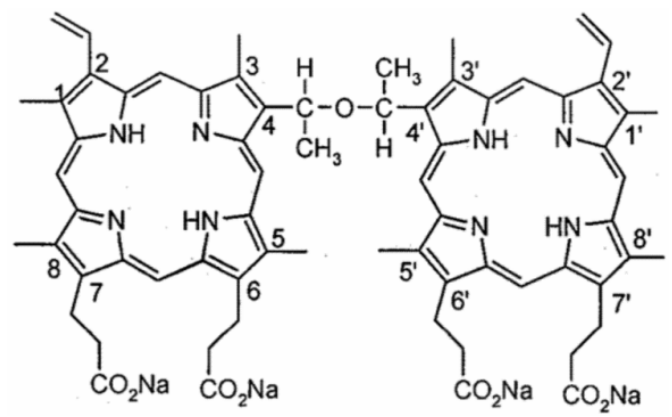

Fig. 1 The chemical structure of DVDMS.

\section{Reagents}

3-(4,5-Dimethylthiazol-2-yl)-2,5-diphenyltertraz olium bromide tetrazolium (MTT), $N$-acetylcysteine (NAC), paraformaldehyde, Triton X-100, bovine serum albumin (BSA), crystal violet, and HO 33342 were purchased from Sigma-Aldrich (St. Louis, MO, USA). 2',7'-Dichlorodihydrofluo-rescein-diacetate (DCFHDA) and FITC-phalloidin were from Molecular Probes Inc. (Eugene, OR, USA). Primary antibody against proliferating cell nuclear antigen (PCNA) was purchased from Abcam (Cambridge, UK). Secondary antibodies were obtained from Zhong Shan Golden Bridge Biotechnology (Beijing, China). Glutamic-pyruvic transaminase (GPT) and glutamic-oxalacetic transaminase (GOT) assay kits were 
provided by Nanjing Jiancheng Bioengineering Institute (Nanjing, China).

\section{Spectrophotometric assay}

The absorption spectra of DVDMS with a range of concentrations (10-40 $\mu \mathrm{M})$ in $50 \mathrm{mM}$ Tris- $\mathrm{HCl}-\mathrm{NaCl}$ buffer solution $(\mathrm{pH}=7.2$ and $[$ Tris- $\mathrm{HCl}]=[\mathrm{NaCl}]=50$ $\mathrm{mM}$ ) were recorded between $300 \mathrm{~nm}$ and $700 \mathrm{~nm}$ with a resolution of $1 \mathrm{~nm}$ using a multi-volume spectrophotometer system (Epoch, BioTek, USA). In addition, the emission spectra of DVDMS were recorded with a resolution of $1 \mathrm{~nm}$ using a fluorescence microplate reader (Enspire, PE, USA). The absorption spectra and emission spectra of DVDMS (constant $20 \mu \mathrm{M}$ ) were also determined while solution acidity $(\mathrm{pH})$ and the ionic strength of Tris- $\mathrm{HCl}-\mathrm{NaCl}$ buffer solution were adjusted.

\section{Tumor cell lines}

The 4T1 murine breast cancer cell line was obtained from the Department of Basic Medicine, Union Medical College, Beijing, China. The cells were cultured in Dulbecco's modified Eagle's medium (DMEM, Gibco, Life Technologies, Inc.) supplemented with $10 \%$ fetal bovine serum (FBS, Hyclone, USA), $100 \mathrm{U} / \mathrm{ml}$ penicillin, $100 \mu \mathrm{g} / \mathrm{ml}$ streptomycin, and 1 $\mathrm{mM}$ L-glutamine. Cultures were maintained at $37^{\circ} \mathrm{C}$ with humidity and $5 \% \mathrm{CO}_{2}$.

\section{Animals}

The BALB/c mice (female, 18-20 g body weight) were supplied by the Experimental Animal Center of Fourth Military Medical University (FMMU) (Xi'an, China). They were housed in an air-conditioned room at $23^{\circ} \mathrm{C} \pm 2{ }^{\circ} \mathrm{C}$ with free access to food and water and were maintained on a $12 \mathrm{~h}$ light-dark cycle. For the experiments, $1 \times 10^{6} 4 \mathrm{~T} 1$ cells in $0.1 \mathrm{ml}$ physiological saline were subcutaneously injected into the left oxter region of $\mathrm{BALB} / \mathrm{c}$ mice. When tumors reached an average volume of $62.5 \mathrm{~mm}^{3}$ (range $50-70 \mathrm{~mm}^{3}$, about 5-7 days post injection), the mice were analyzed. All experiments using live animals were carried out with approval from the university's Institutional Animal Care and Use Committee.

\section{Photodynamic treatment}

A semiconductor laser (excitation wavelength: 635 nm; manufacturer: Institute of Photonics \& Photon Technology, Department of Physics, Northwest University, Shaanxi, China) was used for PDT. Laser irradiance was measured using a radiometer system (Institute of Photonics \& Photon Technology, Department of Physics, Northwest University). For in vitro experiments, the laser was used with a power intensity of $23.85 \mathrm{~mW} / \mathrm{cm}^{2}$ and an irradiation time of 1-5 min such that the final dose of light ranged from
1.43 to $7.15 \mathrm{~J} / \mathrm{cm}^{2}$. For in vivo experiments, the laser was used with a power intensity of $416.7 \mathrm{~mW} / \mathrm{cm}^{2}$ and an irradiation time of 2-6 min such that the final dose of light ranged from 50 to $150 \mathrm{~J} / \mathrm{cm}^{2}$.

\section{Cell viability assays}

Cell viability was evaluated using a MTT assay and a colony formation assay. For the MTT assay, 4T1 cells $\left(2 \times 10^{5}\right.$ cells $\left./ \mathrm{ml}\right)$ were incubated with $4 \mu \mathrm{M}$ DVDMS in 24-well culture plates (Corning Inc., NY, USA) for $4 \mathrm{~h}$ and then exposed to $1.43,4.29$, or 7.15 $\mathrm{J} / \mathrm{cm}^{2}$ of light. After treatment, cells were cultured in 96-well plates, for $24 \mathrm{~h}$. Cell viability was then determined by adding $10 \mu \mathrm{l}$ MTT solution $(5 \mathrm{mg} / \mathrm{ml}$ in PBS) to each well followed by incubation for $4 \mathrm{~h}$ at $37^{\circ} \mathrm{C}$ with $5 \% \mathrm{CO}_{2}$. The MTT mixture was removed and $150 \mu \mathrm{l}$ DMSO was added to each well. Samples were agitated on a shaker for $15 \mathrm{~min}$, and the absorbance at $570 \mathrm{~nm}$ was recorded using a micro-plate reader (Bio-Tek, ELX800, USA) with a reference value at $630 \mathrm{~nm}$. The cell viability of treated samples was then obtained by comparison with the incubated but non-treated control.

A colony formation assay was performed to evaluate the long-term proliferative potential of 4T1 cells following PDT treatment. Cells were seeded onto 24-well plates at a density of 400 cells/well and cultured for 7 days. The medium was changed every 3 days until visible colonies formed. The experiment was carried out in triplicate. Colonies were fixed with $4 \%$ paraformaldehyde at $4^{\circ} \mathrm{C}$ for $15 \mathrm{~min}$ and then stained using Giemsa for $30 \mathrm{~min}$. The samples were washed with PBS and dried out at room temperature (RT). The number of stained colonies that contained at least 50 cells was manually counted. Proliferation potential was calculated using the following equation: relative colony formation rate $(\%)=$ number of colonies with at least 50 cells in the treatment group/number of colonies with at least 50 cells in the control group $\times 100 \%$.

To compare phototoxicity, $4 \mathrm{~T} 1$ cells $\left(2 \times 10^{5}\right.$ cells $/ \mathrm{ml}$ ) were incubated with either DVDMS (5 $\mu \mathrm{g} / \mathrm{ml})$ or PF $(5 \mu \mathrm{g} / \mathrm{ml})$ in 24 -well culture plates for 4 $\mathrm{h}$. The cells were exposed to an equivalent light dose $\left(4.29 \mathrm{~J} / \mathrm{cm}^{2}\right)$. Cell viability was then evaluated using the MTT assay and colony formation assay.

\section{Measuring intracellular ROS production}

2,7-DCF-diacetate

(DCFH-DA),

a

non-fluorescent cell-permeant compound, is hydrolyzed by endogenous esterases within the cell and the de-esterified product can be converted into the fluorescent compound DCF upon oxidation by intracellular ROS. It has been reported the specificity of DCF is quite broad, with a spectrum that includes $\mathrm{H}_{2} \mathrm{O}_{2}$, 
$\cdot \mathrm{OH}, \mathrm{O}_{2}^{-}, \mathrm{ONOO}^{-}, \mathrm{OCl}^{-}$, and ${ }^{1} \mathrm{O}_{2}[17,18]$, and it has been used as a common probe for intracellular ROS detection in PDT studies [19, 20, 21]. Briefly, cells were incubated with $10 \mu \mathrm{M}$ DCHF-DA at $37^{\circ} \mathrm{C}$ for $30 \mathrm{~min}$ prior to PDT treatment. At $2 \mathrm{~h}$ after PDT treatment, cells were harvested and subjected to flow cytometry analysis (Guava easyCyte 8HT, Millipore, USA). Histograms were analyzed using FCS Express V3 software (De Novo Software, Thornhill, OT, Canada).

For experiments investigating the role of ROS production in the phototoxicity of DVDMS, $5 \mathrm{mM}$ NAC, a ROS scavenger, was added to the medium for $1 \mathrm{~h}$ before DVDMS treatment. Cell viability was evaluated using the MTT assay.

\section{Cell motility}

Cell motility was evaluated using scratch wound-healing and transwell assays. For the scratch wound-healing assay, cells in each group were wounded immediately after treatment by scratching with a sterile pipette tip. Subsequently, samples were washed with PBS. Phase contrast images were taken using a Nikon microscope at 0 and $24 \mathrm{~h}$ time points.

For the transwell assay, $2 \times 10^{5}$ cells were seeded into the top chamber of a Corning chamber (polycarbonate filter with 8 -mm pore size inserts, Corning Pharmingen, San Diego, CA) in serum-free medium containing $0.3 \%$ BSA. Medium containing $10 \%$ serum was placed in the lower chamber. After $24 \mathrm{~h}$, cells that migrated to the underside of the membrane were detected using a $0.1 \%$ crystal violet solution. The assay was repeated three times with three replicates each. Cells that migrated to the underside of the membrane were quantified using light microscopy (Nikon Eclipse TE2000-S, Japan). Crystal violet was dissolved using a $33 \%$ acetic acid, and the OD ratio at $570 \mathrm{~nm}$ was determined using a microplate reader.

\section{Scanning electron microscope (SEM) imaging}

Twenty-four hours after PDT treatment, cells were fixed using 2.5\% glutaraldehyde in PBS for $24 \mathrm{~h}$. Samples were washed with PBS and dehydrated using graded alcohol $(30 \%, 50 \%, 70 \%, 80 \%, 90 \%$, $95 \%, 100 \%$ ), critical point-dried from liquid $\mathrm{CO}_{2}$ and gold sputtered. The surfaces of the cells were observed by scanning electron microscope (S-3400N, Hitachi, Japan).

\section{F-actin cytoskeleton analysis}

Cells were fixed using $4 \%$ paraformaldehyde in PBS for $10 \mathrm{~min}$ and then permeabilized with $0.1 \%$ Triton X-100 in PBS for 6 min. Samples were blocked with 1\% BSA in PBS at RT for $1 \mathrm{~h}$. Cells were stained with $10 \mu \mathrm{g} / \mathrm{ml}$ FITC-phalloidin at $37^{\circ} \mathrm{C}$ in the dark for 1 h. Nuclei were stained with HO 33342 at RT for 15 min. Between each step, cells were washed three times with PBS for $5 \mathrm{~min}$. Images were obtained using laser scanning confocal microscopy (TCS SP5, Leica, Germany).

\section{Detection of DVDMS concentration in plasma and tissue}

DVDMS was administered to 4T1 tumor-bearing mice at a dose of $2.0 \mathrm{mg} / \mathrm{kg}$ using intravenous injection into the caudal vein. At each time point $(0.5,1,2$, $6,12,24,48$, and $72 \mathrm{~h}$ ) post injection, $0.5 \mathrm{ml}$ blood samples were obtained by removing the eyeballs of the mice. Immediately, blood was placed into $1.5 \mathrm{ml}$ heparin-coated tubes and centrifuged to separate the plasma. The mice were euthanized at 1, 2, 6, 12, 24, 48, or $72 \mathrm{~h}$ after injection of DVDMS using cervical dislocation. Tumor and normal tissue were excised immediately, rinsed in PBS, blotted dry, and weighed. Plasma $(0.1 \mathrm{ml})$ was combined with $1.5 \mathrm{ml}$ of a PBS/methanol mixture $(1 / 2, \mathrm{v} / \mathrm{v})$. Tissue $(0.2 \mathrm{~g})$ was homogenized in $1.5 \mathrm{ml}$ of PBS using a tissue grinder, followed by centrifugation at $3000 \mathrm{rpm}$ at $4^{\circ} \mathrm{C}$ for 5 min. The supernatant $(0.5 \mathrm{ml})$ was combined with 1 $\mathrm{ml}$ of methanol and centrifuged. The supernatant was prepared for detection. The DVDMS concentration was estimated by detecting the fluorescence intensity of the tissue extracts using a fluorescence photometer (LS-55, PE, USA). A standard curve was generated using known concentrations of DVDMS in a PBS/methanol mixture $(1 / 2, \mathrm{v} / \mathrm{v})$. The background auto-fluorescence was eliminated using calculations from corresponding tissue digests in control group mice.

\section{DVDMS-PDT in the 4T1 xenograft model}

The tumor-bearing mice were randomly divided into eight groups: (1) control, (2) $10 \mathrm{mg} / \mathrm{kg} \mathrm{PF}+100$ $\mathrm{J} / \mathrm{cm}^{2}$ light, (3) $2 \mathrm{mg} / \mathrm{kg}$ DVDMS, (4) $0.5 \mathrm{mg} / \mathrm{kg}$ DVDMS + $50 \mathrm{~J} / \mathrm{cm}^{2}$ light, (5) $1 \mathrm{mg} / \mathrm{kg}$ DVDMS + 50 $\mathrm{J} / \mathrm{cm}^{2}$ light, (6) $2 \mathrm{mg} / \mathrm{kg}$ DVDMS + $50 \mathrm{~J} / \mathrm{cm}^{2}$ light, (7) $2 \mathrm{mg} / \mathrm{kg}$ DVDMS + $100 \mathrm{~J} / \mathrm{cm}^{2}$ light, and (8) $2 \mathrm{mg} / \mathrm{kg}$ DVDMS $+150 \mathrm{~J} / \mathrm{cm}^{2}$ light. The control mice were injected with $0.2 \mathrm{ml}$ of PBS. Injections were performed into the caudal vein, and $24 \mathrm{~h}$ post injection, the mice were exposed to the indicated dose of light. Hair from the tumor region was removed using depilatory cream.

Tumor volumes were measured for 17 days after treatment. The long (a) and short (b) diameters of the tumors were measured using slide calipers every second day after treatment, and the body weight was also measured. The mean tumor volume was calculated using the formula: $\mathrm{ab}^{2} / 2$, and the volume inhibition ratio was calculated as follows: (1-average tumor volume of treated group/average tumor volume of the control group) $\times 100 \%$. Nineteen days after 
treatment, the mice were sacrificed, and the tumors were removed and weighed. In addition, the lungs were removed and fixed in Bouin's solution for $24 \mathrm{~h}$. The pulmonary nodules were photographed and counted.

For the survival study, the tumor-bearing mice were randomly divided into four groups: (1) Control, (2) $2 \mathrm{mg} / \mathrm{kg}$ DVDMS, (3) $2 \mathrm{mg} / \mathrm{kg}$ DVDMS + $50 \mathrm{~J} / \mathrm{cm}^{2}$ light, and (4) $10 \mathrm{mg} / \mathrm{kg} \mathrm{PF}+100 \mathrm{~J} / \mathrm{cm}^{2}$ light. The mice were either allowed to die naturally or sacrificed when the tumor burden was greater than $20 \%$ of the body. In both cases, the number of days survived post tumor inoculation was recorded.

\section{Hematoxylin and eosin (H\&E) staining}

Tumors and major organs was fixed using 10\% formalin for at least $24 \mathrm{~h}$. Samples were then paraffin-embedded, sectioned, and stained with H\&E. Histopathological changes were observed using light microscopy (Nikon E600, Japan).

\section{Immunohistochemistry}

Paraffin-embedded tumor tissue sections $(7 \mu \mathrm{m}$ thick) were dewaxed, rehydrated, and then treated with heat-mediated antigen retrieval using $10 \mathrm{mM}$ citrate buffer ( $\mathrm{pH}$ 6.0) for $15 \mathrm{~min}$. Sections were permeabilized with $0.2 \%$ Triton X-100 for $15 \mathrm{~min}$. Sections were immersed in 3\% hydrogen peroxide solution for $10 \mathrm{~min}$ to quench endogenous peroxidase activity. Non-specific binding was prevented by incubation with $5 \%$ normal goat serum for $15 \mathrm{~min}$. The sections were then incubated with anti-PCNA antibody (1: 8000 dilutions) overnight at $4^{\circ} \mathrm{C}$. Antibody binding was detected using horseradish peroxidase-conjugated secondary antibody for $20 \mathrm{~min}$ at $37^{\circ} \mathrm{C}$. Sections were visualized using diaminobenzidine (DAB) solution (ZSGB-Bio company, Beijing, China) counterstained with hematoxylin, and observed using light microscopy.

\section{Evaluation of acute hepatic damage}

When tumor volume reached approximately 62.5 $\mathrm{mm}^{3}, 60$ ICR mice were randomly divided into 4 groups (15 in each group) and were injected with PBS or DVDMS ( $2 \mathrm{mg} / \mathrm{kg}, 4 \mathrm{mg} / \mathrm{kg}$, or $6 \mathrm{mg} / \mathrm{kg}$ ) through the caudal vein. Mice were housed in the dark and blood samples were obtained from the eyeballs at 12 h, $24 \mathrm{~h}, 48 \mathrm{~h}, 72 \mathrm{~h}$, and $96 \mathrm{~h}$ after injection. Levels of GPT and GOT were determined by using GPT and GOT kits.

\section{Statistical analysis}

SPSS 19.0 software (SPSS Inc., Chicago) was used for statistical analysis. Values are expressed as mean \pm standard deviation of three samples obtained from three independent experiments. Statistical compari- sons were made using one-way analysis of variance (ANOVA) and multiple comparisons between groups were performed using Turkey's test and $p<0.05$ was considered statistically significant, while $p<0.01$ was highly significant.

\section{Results}

\section{Spectrophotometric analysis of DVDMS}

DVDMS had five distinct spectral peaks at 362, 516, 548, 579 and $631 \mathrm{~nm}$, and the maximum peak was at approximately $362 \mathrm{~nm}$ (Fig. 2A, a). The peak emission for fluorescence was observed at $642 \mathrm{~nm}$ (Fig. 2A, b). The spectral characteristics of DVDMS were independent from DVDMS concentration. The peak absorbance and emission values indicated a linear dependence for DVDMS concentration, which may suggest that DVDMS was present in monomeric form.

The acidity $(\mathrm{pH})$ and ionic strength of the buffer solution caused changes of peak values and positions (Fig. 2B C), suggesting that the characteristics of DVDMS had changed concurrent with the alteration in $\mathrm{pH}$ and ionic strength.

\section{Phototoxic effects of DVDMS}

To examine the phototoxicity of DVDMS in vitro, we exposed 4T1 cells to a light source in the presence of $4 \mu \mathrm{M}$ DVDMS. The phototoxicity of DVDMS was enhanced by increasing the dose of administered light (Fig. 3A). The calculated cell viability for DVDMS-PDT using 1.43, 4.29, and $7.15 \mathrm{~J} / \mathrm{cm}^{2}$ light doses was $79.31 \%$ ( $p<0.05$ vs. control and DVDMS alone groups), $54.88 \%(p<0.01$ vs. control and DVDMS alone groups) and $33.91 \%(p<0.01$ vs. control and DVDMS alone groups), respectively. When compared with PF, the most widely used photosensitizer in clinical PDT therapy, a significant cell viability decrease $(p<0.01)$ was observed in DVDMS-PDT. These results indicate that DVDMS is more effective at reducing $4 \mathrm{~T} 1$ cell viability than $\mathrm{PF}$.

To further evaluate the long-term proliferative potential of 4T1 cells following PDT treatments, a colony formation assay was performed. The assay confirmed the reduced proliferative potential induced by DVDMS-PDT treatments in a light-dose dependent manner (Fig. 3B) and DVDMS-PDT inhibited colony formation compared with PF-PDT $(p<0.01)$.

\section{The phototoxic effects of DVDMS are medi- ated by ROS production}

PDT-induced cell death is thought to occur through generation of intracellular ROS [17]. Therefore, we measured intracellular ROS levels using DCFH-DA staining after DVDMS-PDT. Flow cytometry analyses indicated that exposure of cells to DVDMS-PDT treatment significantly enhanced intra- 
cellular ROS levels (Fig. 4A). The mean fluorescence intensity of DCF in DVDMS-PDT group was increased compared with the control group and the DVDMS alone group (Fig. 4B, $p<0.01$ ). To further investigate the role of ROS in PDT-induced cell death

A

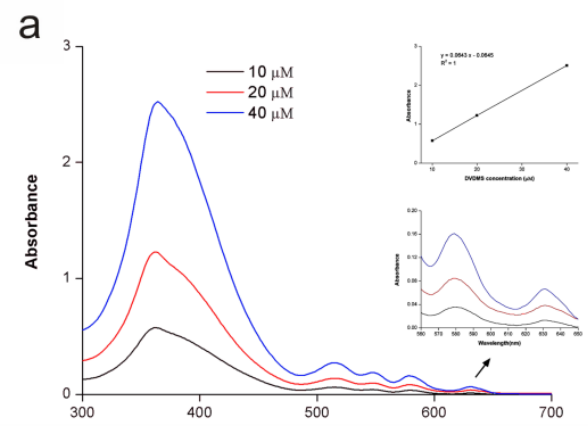

B

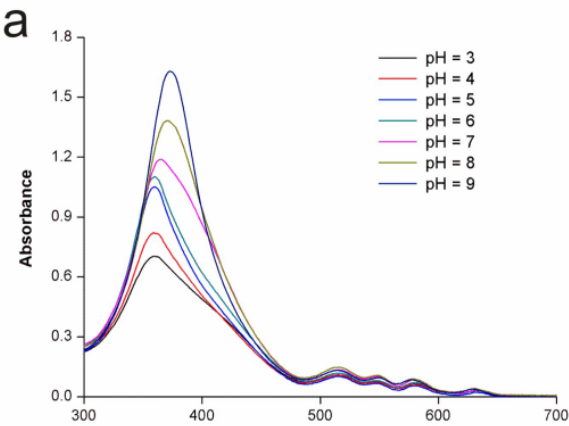

C a

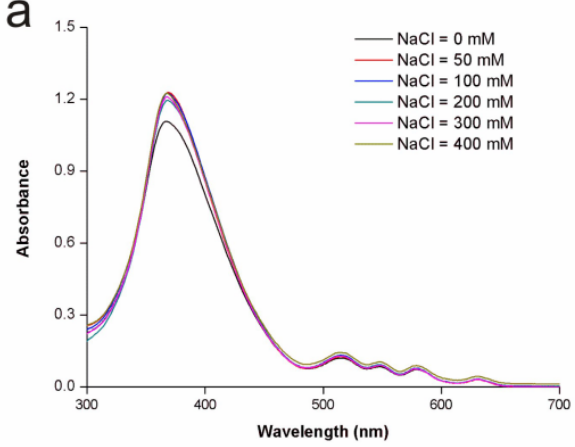

in $4 \mathrm{~T} 1$ cells, cells were pretreated with NAC. The viability of 4T1 cells in DVDMS-PDT group increased to above $90 \%$ with NAC pretreatment (Fig. 4C). These results suggest that ROS plays a key role in DVDMS-PDT induced cytotoxicity in 4T1 cells.
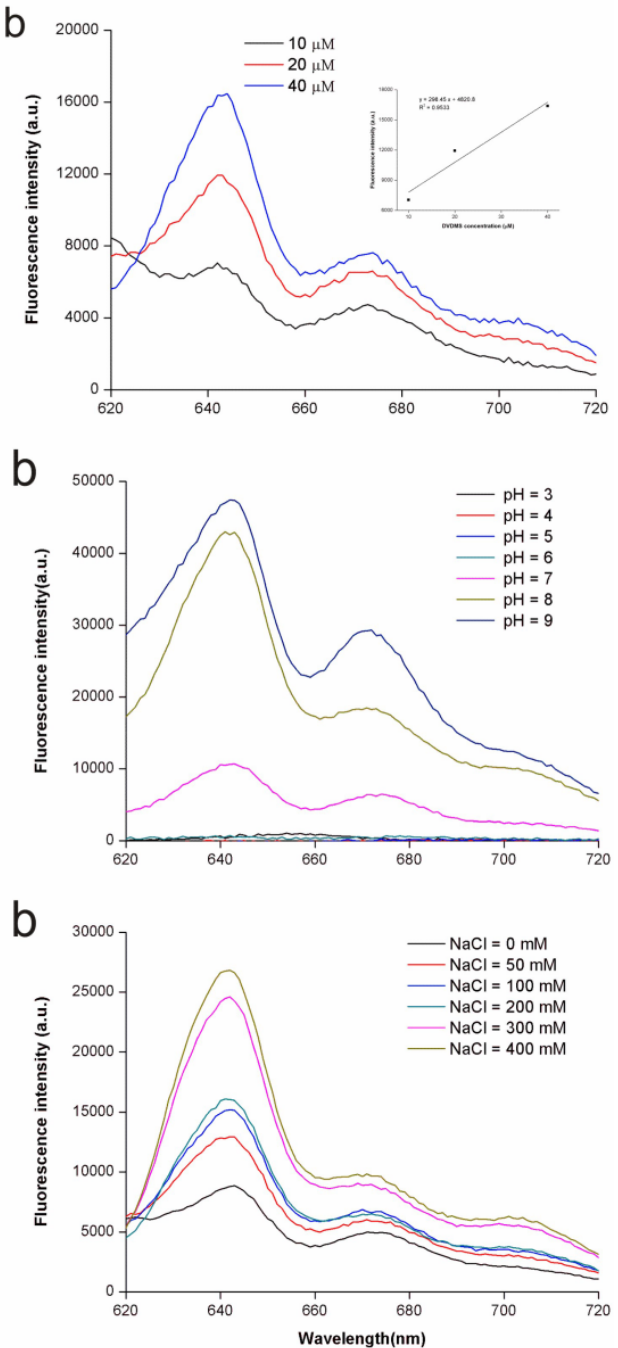

Fig. 2 Spectrophotometric analysis of DVDMS. A: The absorption (a) and fluorescence emission (b) spectra of DVDMS in $50 \mathrm{mM}$ Tris-HCl-NaCl buffer solution ( $\mathrm{pH}$ 7.2). B: The absorption (a) and fluorescence emission (b) spectra of DVDMS in Tris-HCl-NaCl buffer solution at different $\mathrm{pH}$; $\mathrm{C}$ : The absorption (a) and fluorescence emission (b) spectra of DVDMS in Tris- $\mathrm{HCl}-\mathrm{NaCl}$ buffer solution at different $\mathrm{NaCl}$ concentrations.

A

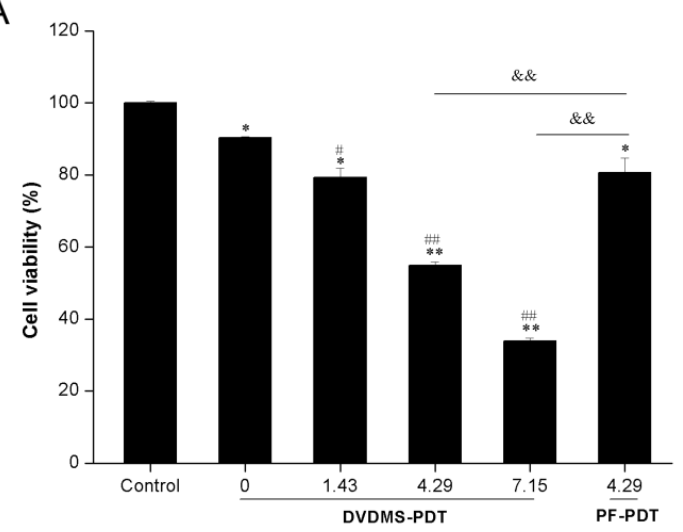

B

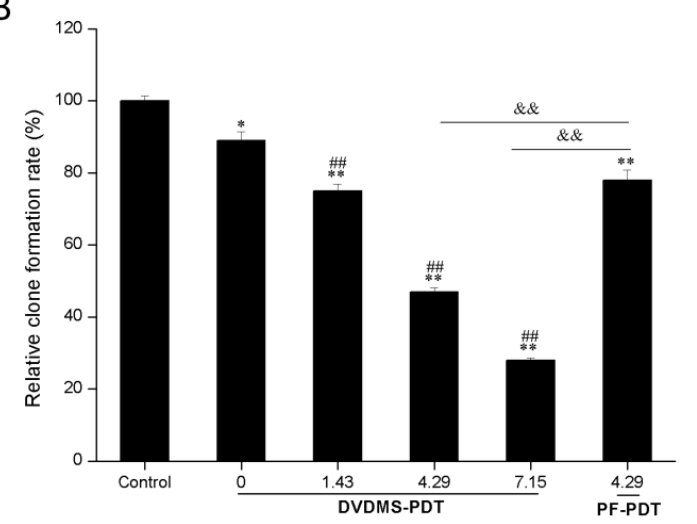

Fig. 3 In vitro phototoxicity of DVDMS on 4T1 cells as determined by MTT assay (A) and colony formation assay (B). Error bars represent the SD from three independent experiments. $* p<0.05$, $* * p<0.01$ versus control, \# $p<0.05$, \# $p<0.01$ versus DVDMS alone, \&\&p<0.01 PF-PDT group versus DVDMS-PDT group. 
A
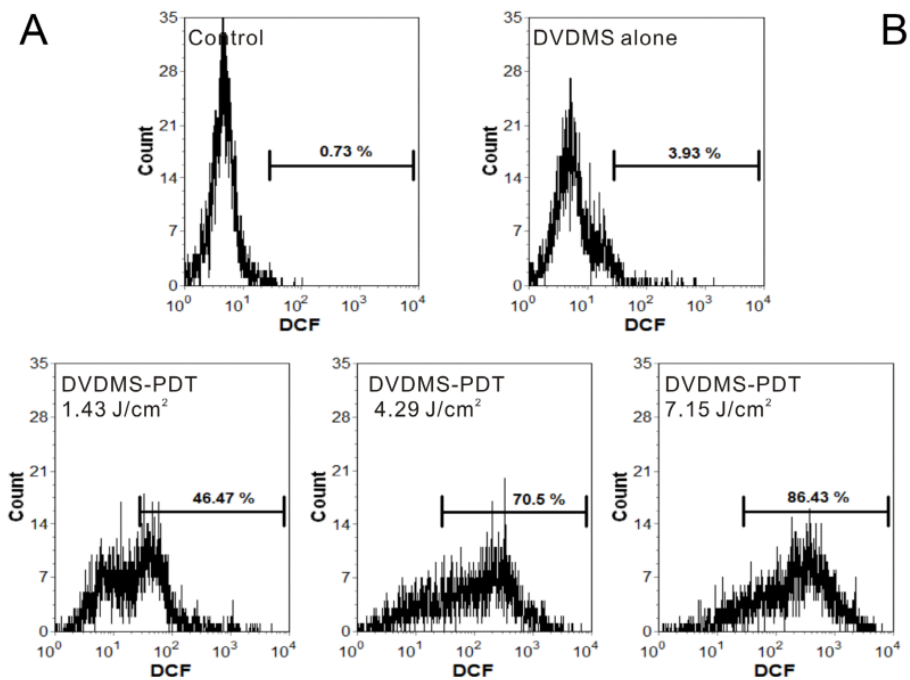

$\mathrm{B}$

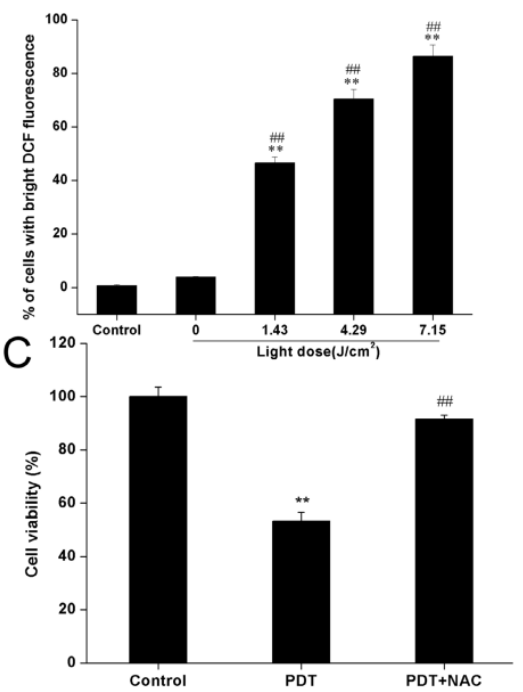

Fig. 4 The phototoxic effects of DVDMS are mediated by ROS production. A, B: Measurement of intracellular ROS in 4T1 cells. Error bars represent the SD from three independent experiments. $* * p<0.01$ versus control, \# $p<0.01$ versus DVDMS alone. C: Effect of ROS scavenger NAC on PDT induced cytotoxicity in 4 T1 cells. Error bars represent the SD from three independent experiments. $* * p<0.01$ PDT versus control, \#\# $p<0.01$ PDT + NAC versus PDT.

\section{DVDMS-PDT inhibits cell migration in 4T1 cells}

Cell migration was assessed using scratch wound-healing and transwell assays. In the scratch wound-healing assay, cells in the untreated and DVDMS alone groups filled the wound completely after $24 \mathrm{~h}$, while the DVDMS-PDT groups exhibited reduced migration into the wound in a dose-dependent manner (Fig. 5A). The PF-PDT group also exhibited a decrease in migration; however, the effect was less than that for the DVDMS-PDT group at the same light dose.

The effect of PDT on cell migration was further explored using a transwell assay. Numerous cells in both the control and DVDMS alone groups migrated to the underside of the well at $24 \mathrm{~h}$ post treatment, and there was a significant decrease in cell migration in the PDT groups (Fig. 5B). In the DVDMS-PDT groups, the inhibition of migration was dose-dependent. Analysis of the OD ratio of crystal violet indicated similar results. The findings showed $36.83 \%(p<0.01), 54.57 \%(p<0.01)$, and $70.89 \%(p<$ $0.01)$ decreases in cell migration rate in the DVDMS-PDT groups with $1.43,4.29$, and $7.15 \mathrm{~J} / \mathrm{cm}^{2}$ light exposure, respectively, while only $13.48 \%(p<$ 0.05 ) decrease was seen in the DVDMS alone group as compared to the control group. In addition, $32.04 \%(p$ $<0.01$ ) decrease was seen in PF-PDT with the 4.29 $\mathrm{J} / \mathrm{cm}^{2}$ group as compared to the control group. The decrease was much lower than that for the DVDMS-PDT group with the same light dose $(p<$ $0.01)$.
Microvilli of tumor cells play a key role in their response to environmental changes, adhesion, migration, and metastasis [22]. Therefore we examined the effects of PDT on microvilli structure using SEM. Control and DVDMS alone cells had intact cell membranes with regular arrays of microvilli distribution. DVDMS-PDT resulted in cell body shrinkage and distortion of microvilli (Fig. 5C).

Since cytoskeletal elements are known to regulate cell migration [22, 23, 24], we evaluated the effects of PDT on the organization of the F-actin network. Cells in the control and DVDMS alone groups had a regular array of well-defined actin filaments that were evenly distributed throughout the cytoplasm (Fig. 5D). Cells in DVDMS-PDT groups had disorganized actin filaments in a light-dose dependent manner. There were no detectable actin filaments in the DVDMS-PDT group with a light dose of $7.15 \mathrm{~J} / \mathrm{cm}^{2}$. Cells treated with PF-PDT with a light dose of 4.29 $\mathrm{J} / \mathrm{cm}^{2}$ had less actin disorganization than the DVDMS-PDT group at the same light exposure.

\section{DVDMS concentration in plasma and tissue}

A standard curve was generated according to the fluorescence intensity of known gradient concentration of DVDMS (Fig. 6A), and the equation was as follows: $y=1.9625 x+10.118\left(R^{2}=0.9993\right)$. Based on the standard curve of DVDMS, the concentration of DVDMS after injection in the plasma and tissues could be calculated by the fluorescence intensity. After injection, the concentration of DVDMS in the blood plasma decreased rapidly in the first $6 \mathrm{~h}$. Then the concentration decreased less rapidly and stabilized at a low level by $72 \mathrm{~h}$ (Fig. 6B). 

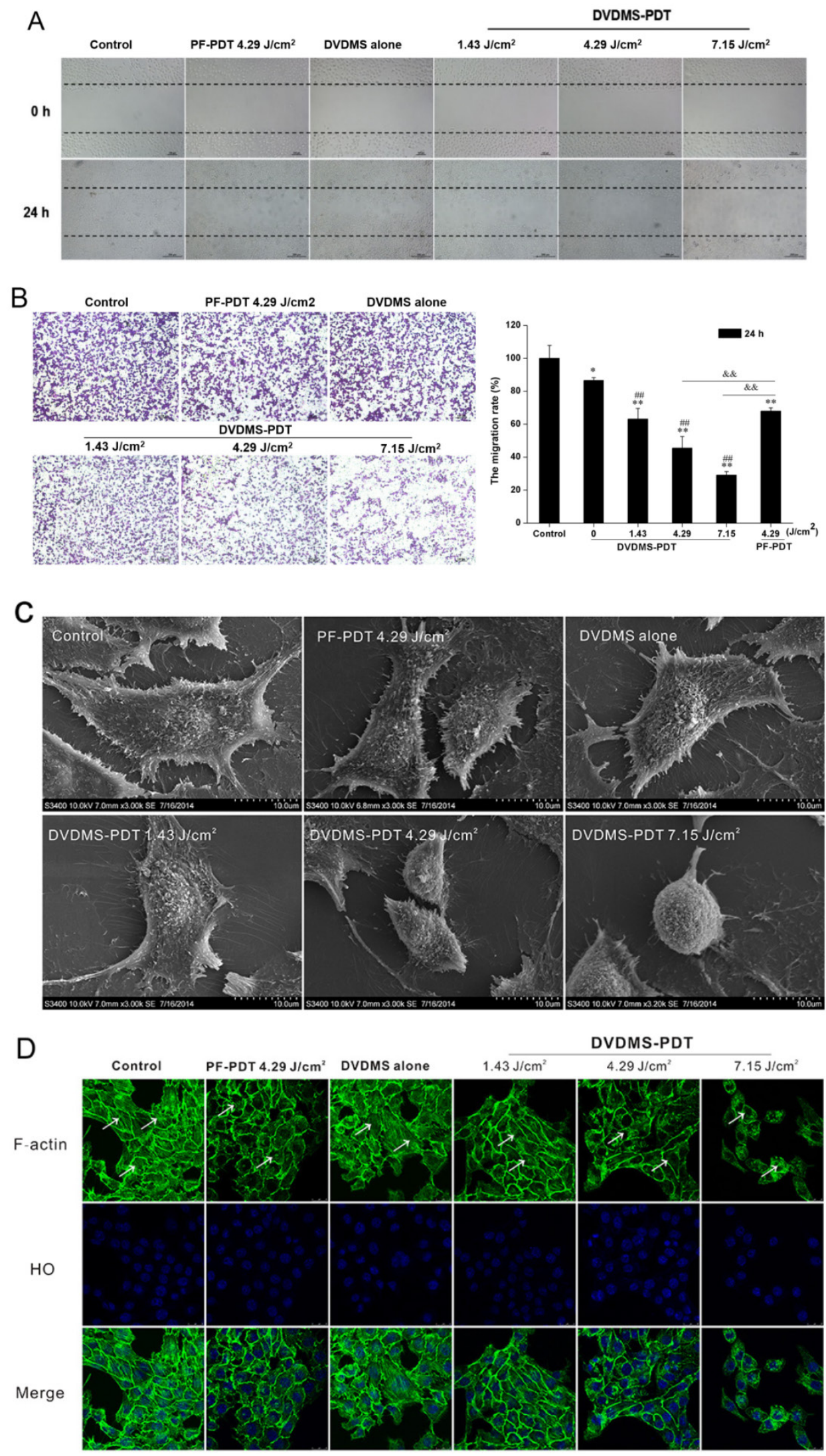

Fig. 5 DVDMS-PDT inhibits the cell motility of 4T1 cells. A: The effects of the indicated treatments on cell migration using a scratch wound-healing assay are shown. B: Analyses of cell migration using a transwell assay. Error bars represent the SD from three independent experiments. $* p<0.05$, $* * p<0.01$ versus control, \# $p<0.01$ versus DVDMS alone, \&\&p $<0.01$ PF-PDT group versus DVDMS-PDT group. C: Scanning electron micrographs of 4 T1 cells at $24 \mathrm{~h}$ after different the indicated treatments are shown. D: Images of the F-actin cytoskeleton in 4Tl cells after the indicated treatments are shown. The representative phenomenon is denoted by white arrows. FITC-phalloidin (green) and HO stained nuclei (blue). 

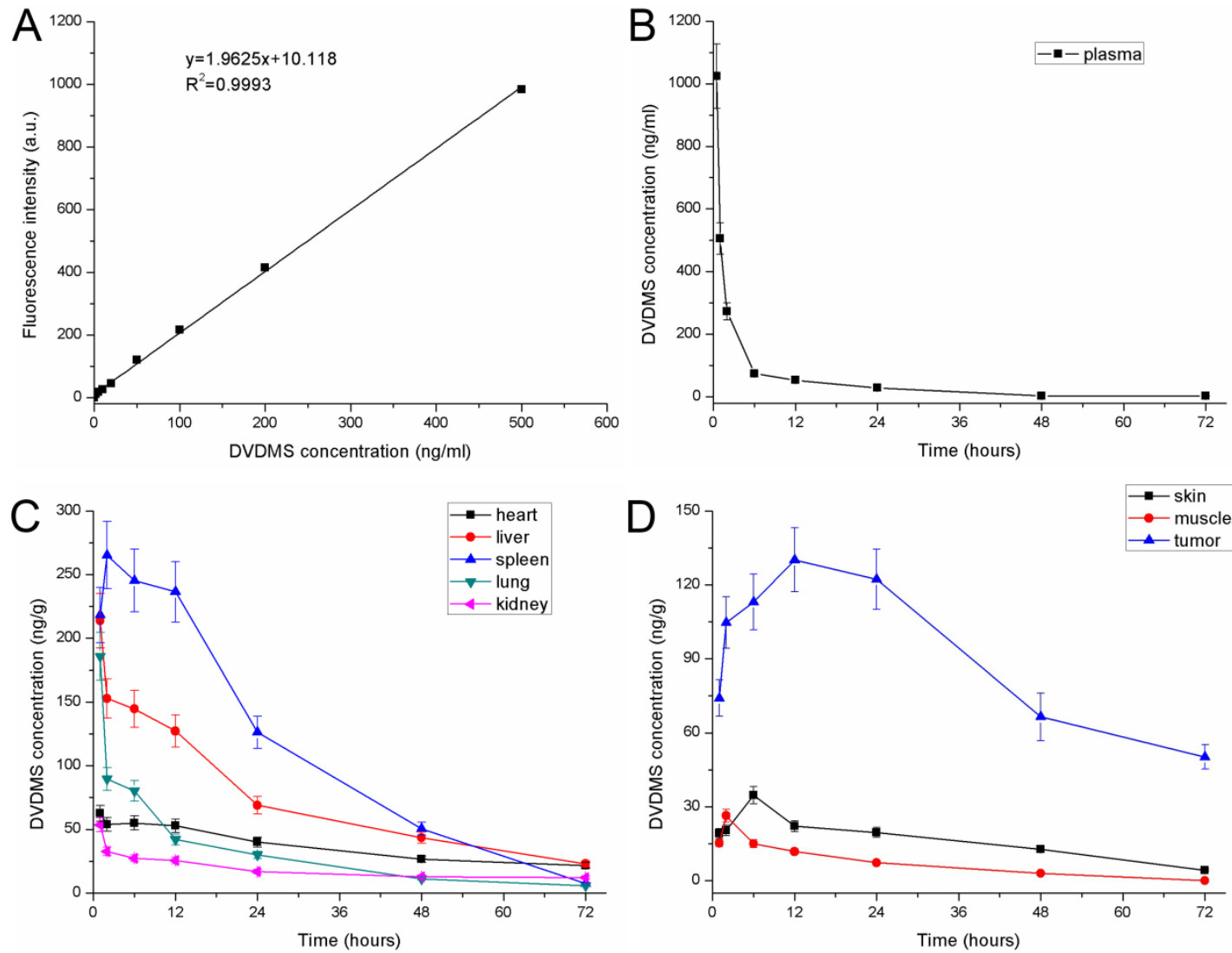

Fig. 6 The pharmacokinetics of DVDMS in 4T1-bearing mice. A: Standard curve of DVDMS. B: DVDMS concentration in plasma after administration. C: The pharmacokinetics of DVDMS in major organs (heart, liver, spleen, lung and kidney). D: The pharmacokinetics of DVDMS in tumor, skin and muscle. Error bars represent the SD from three independent experiments.

The pharmacokinetics of DVDMS in the major organs (heart, liver, spleen, lung, and kidney) are shown in Fig. 6C. The concentration of DVDMS in these organs reached a peak within the first $2 \mathrm{~h}$ after injection, and then decreased rapidly over the next 22 $\mathrm{h}$. By $48 \mathrm{~h}$ and $72 \mathrm{~h}$, the DVDMS concentration in these tissues was very low, which suggests that most DVDMS is excreted during this time. The pharmacokinetics of DVDMS in the tumor, skin, and muscle are shown in Fig. 6D. The concentration of DVDMS in the tumor was higher than that in the surrounding muscle and skin. The concentration increased for the first $6 \mathrm{~h}$ and reached peak at $12 \mathrm{~h}$. At this time point, the concentration was approximately 10 times and 5 times higher than those in the muscle and skin, respectively. Between $12 \mathrm{~h}$ and $24 \mathrm{~h}$, the DVDMS concentration in the tumor was still much higher than those in the muscle and skin. At $48 \mathrm{~h}$ and $72 \mathrm{~h}$, the concentration of DVDMS decreased to a low level. Together, these data suggest that $24 \mathrm{~h}$ after administration might be an appropriate time point for laser radiation.

\section{DVDMS-PDT prolonged the survival time of 4T1 mammary cancer bearing mice}

To investigate the in vivo anti-cancer efficacy of DVDMS-PDT, a 4T1 mouse mammary cancer model was utilized. The anti-cancer efficacy of DVDMS-PDT was compared with that of PF-PDT. DVDMS-PDT significantly prolonged the survival of the 4T1 mammary cancer-bearing mice compared to control and DVDMS alone groups (Fig. 7D, $p<0.01$ ). DVDMS-PDT was also more effective than PF-PDT at increasing survival of tumor-bearing mice $(p<0.05)$.

\section{PDT with DVDMS significantly inhibited tu- mor growth}

Tumor-bearing mice were divided into eight experimental groups to examine DVDMS-PDT phototoxicity in vivo and compare these effects with PF-PDT. Representative mice were photographed at 6, 12 , or 18 days after the corresponding treatments (Supplementary Material: Figure S1). The group treated with $2 \mathrm{mg} / \mathrm{kg}$ DVDMS alone exhibited tumor growth similar to that in the control group, indicating that tumor growth was not affected by DVDMS injection without irradiation. However, tumor size decreased in a dose-dependent manner with increasing DVDMS and light exposure. Using the same light exposure $\left(100 \mathrm{~J} / \mathrm{cm}^{2}\right)$, the tumor size in the $2 \mathrm{mg} / \mathrm{kg}$ DVDMS group was less than in the $10 \mathrm{mg} / \mathrm{kg} \mathrm{PF}$ group, suggesting that DVDMS has an antitumor efficiency superior to PF. 

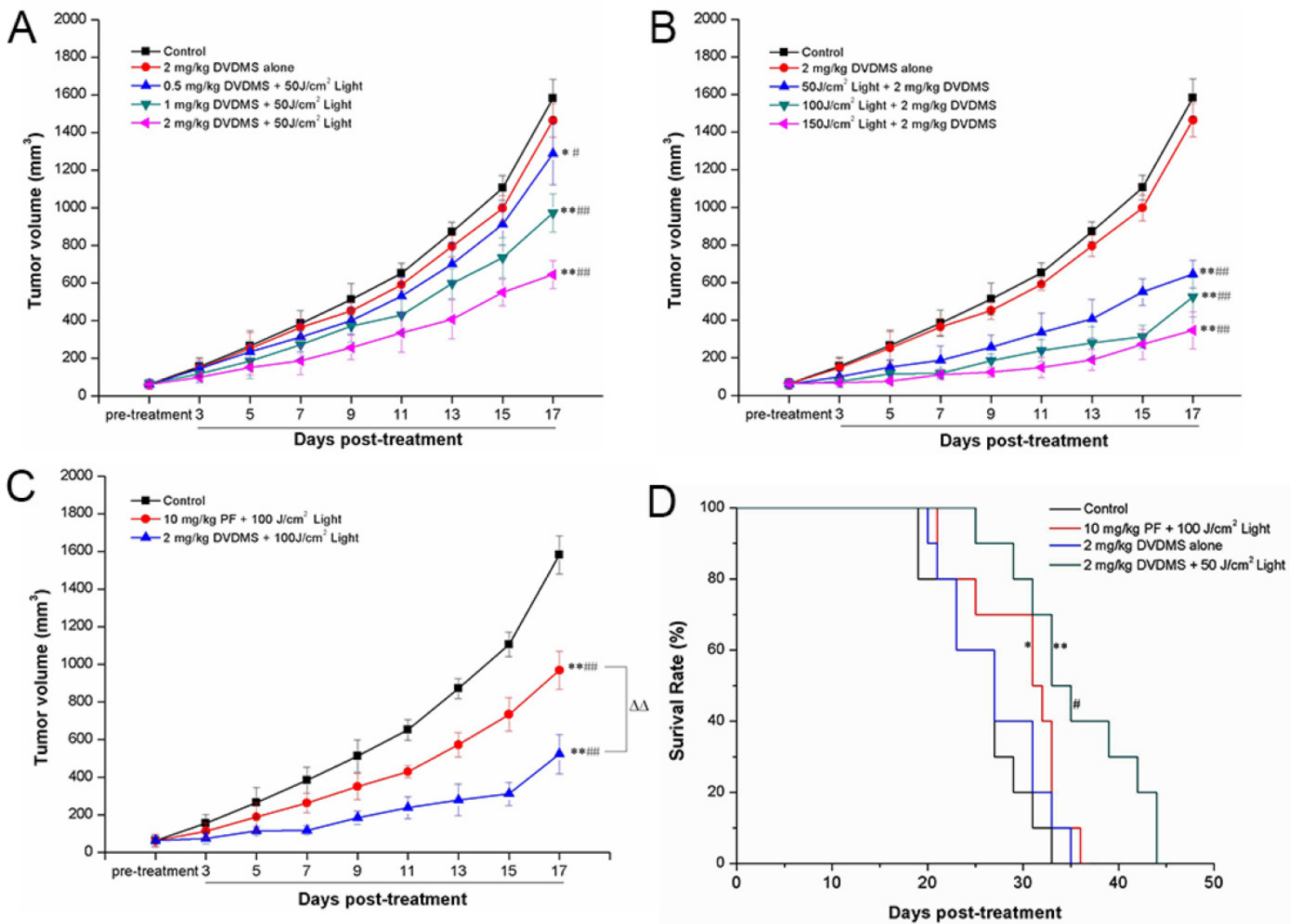

Fig. 7 DVDMS-PDT inhibits tumor growth (A-C) and prolonged the survival time of 4T1 bearing mice (D). A: 4T1-bearing mice were treated with 50 $\mathrm{J} / \mathrm{cm}^{2}$ light and different DVDMS dose (0.5, 1, $\left.2 \mathrm{mg} / \mathrm{kg}\right)$. B: 4T l-bearing mice were treated by $2 \mathrm{mg} / \mathrm{kg}$ DVDMS combined with different light dose $\left(50,100,150 \mathrm{~J} / \mathrm{cm}^{2}\right)$. C: 4Tl-bearing mice were treated by $2 \mathrm{mg} / \mathrm{kg}$ DVDMS or $10 \mathrm{mg} / \mathrm{kg} \mathrm{PF}$ with $100 \mathrm{~J} / \mathrm{cm}^{2}$ light. Error bars represent the SD from three independent experiments. * $p<$ $0.05, * * p<0.01$ versus control, \#p<0.05, \# $p<0.01$ versus $2 \mathrm{mg} / \mathrm{kg}$ DVDMS alone group, $\Delta \Delta p<0.012 \mathrm{mg} / \mathrm{kg}$ DVDMS $+100 \mathrm{~J} / \mathrm{cm}^{2}$ light group versus $10 \mathrm{mg} / \mathrm{kg}$ $\mathrm{PF}+100 \mathrm{~J} / \mathrm{cm}^{2}$ light group. D: Survival curves of $4 \mathrm{Tl}$-bearing mice in different groups. $* p<0.0510 \mathrm{mg} / \mathrm{kg} \mathrm{PF}+100 \mathrm{~J} / \mathrm{cm}^{2}$ light group versus control, $* * p<0.012 \mathrm{mg} / \mathrm{kg}$ DVDMS + $50 \mathrm{~J} / \mathrm{cm}^{2}$ light group versus control and DVDMS alone, $\# p<0.052 \mathrm{mg} / \mathrm{kg}$ DVDMS $+50 \mathrm{~J} / \mathrm{cm}^{2}$ light group versus $10 \mathrm{mg} / \mathrm{kg} \mathrm{PF}+100 \mathrm{~J} / \mathrm{cm}^{2}$ light group.

The tumor volume and tumor weight results were evaluated for each group. Nineteen days after treatment, the tumor volume (Fig. 7A-C) and tumor weight (Supplementary Material: Figure S2) of 4T1 tumors were significantly lower in the DVDMS plus light exposure groups than in the control or DVDMS alone groups. As predicted, these effects exhibited a DVDMS-concentration and light-dose dependence. Using the same light exposure dose, PDT with 2 $\mathrm{mg} / \mathrm{kg}$ DVDMS had a greater effect than PDT with PF at $10 \mathrm{mg} / \mathrm{kg}$. On the $17 \mathrm{th}$ day, the tumor volume inhibition ratios in the (1) $2 \mathrm{mg} / \mathrm{kg}$ DVDMS alone, (2) $0.5 \mathrm{mg} / \mathrm{kg}$ DVDMS $+50 \mathrm{~J} / \mathrm{cm}^{2}$, (3) $1 \mathrm{mg} / \mathrm{kg}$ DVDMS + $50 \mathrm{~J} / \mathrm{cm}^{2}$, (4) $2 \mathrm{mg} / \mathrm{kg}$ DVDMS + $50 \mathrm{~J} / \mathrm{cm}^{2}$, (5) 2 $\mathrm{mg} / \mathrm{kg}$ DVDMS + $100 \mathrm{~J} / \mathrm{cm}^{2}$, (6) $2 \mathrm{mg} / \mathrm{kg}$ DVDMS + $150 \mathrm{~J} / \mathrm{cm}^{2}$ and (7) $10 \mathrm{mg} / \mathrm{kg} \mathrm{PF}+100 \mathrm{~J} / \mathrm{cm}^{2}$ groups as compared with the control were $7.42 \%, 18.61 \%$, $38.51 \%, 59.23 \%, 66.97 \%, 78.12 \%, 38.76 \%$, respectively. On the 19th day, the tumors were photographed and the average tumor weight in each group was calculated. The results showed that the trend of tumor weight inhibition was consistent with tumor volume inhibition (Supplementary Material: Figure S2).

\section{DVDMS-PDT inhibits lung metastasis in vivo}

We next assessed the effects of PDT treatment on lung metastasis. Lungs of mice in the control group and DVDMS alone group displayed multiple metastasized tumors of various sizes on their surface (Fig. 8). In contrast, the surfaces of the lungs from PDT treated mice had reduced lung metastases. The decrease in pulmonary nodules exhibited DVDMS-concentration and light-dose dependence. Lung metastases were inhibited to a greater extent with PDT using $2 \mathrm{mg} / \mathrm{kg}$ DVDMS compared with PDT using $10 \mathrm{mg} / \mathrm{kg}$ PF. Together, these data suggest that PDT-DVDMS is an effective method for inhibiting lung metastasis of breast cancer, possibly with a stronger effect than PF.

\section{Histological and immunohistochemical analy- sis of in vivo anti-tumor effects}

From histopathological analysis using H\&E staining (Fig. 9, upper), we observed that the tumor 
tissue from the control group displayed compact tumor cells with an intact structure. No significant differences between control and DVDMS groups were detected, which suggests that the tumor tissue is not affected by DVDMS injection without irradiation. In the PF- or DVDMS-PDT groups, the tumor tissue was no longer structurally integrated; there were sections devoid of cells and there were numerous nuclear fragments. The tissue damage was more extensive in the DVDMS-PDT group compared with the PF-PDT treated group.

To determine the effect of PDT on cell proliferation in vivo, immunohistochemistry analysis was performed to evaluate the expression level of PCNA, a representative marker of proliferation [25]. PCNA was highly expressed in the control group and DVDMS alone group. PCNA had a reduced expression level in the PDT groups; the level was lower in the DVDMS-PDT group than in PF-PDT group. These data also suggest that the antitumor efficiency of DVDMS-PDT may be superior to that of PF-PDT (Fig. 9, lower).
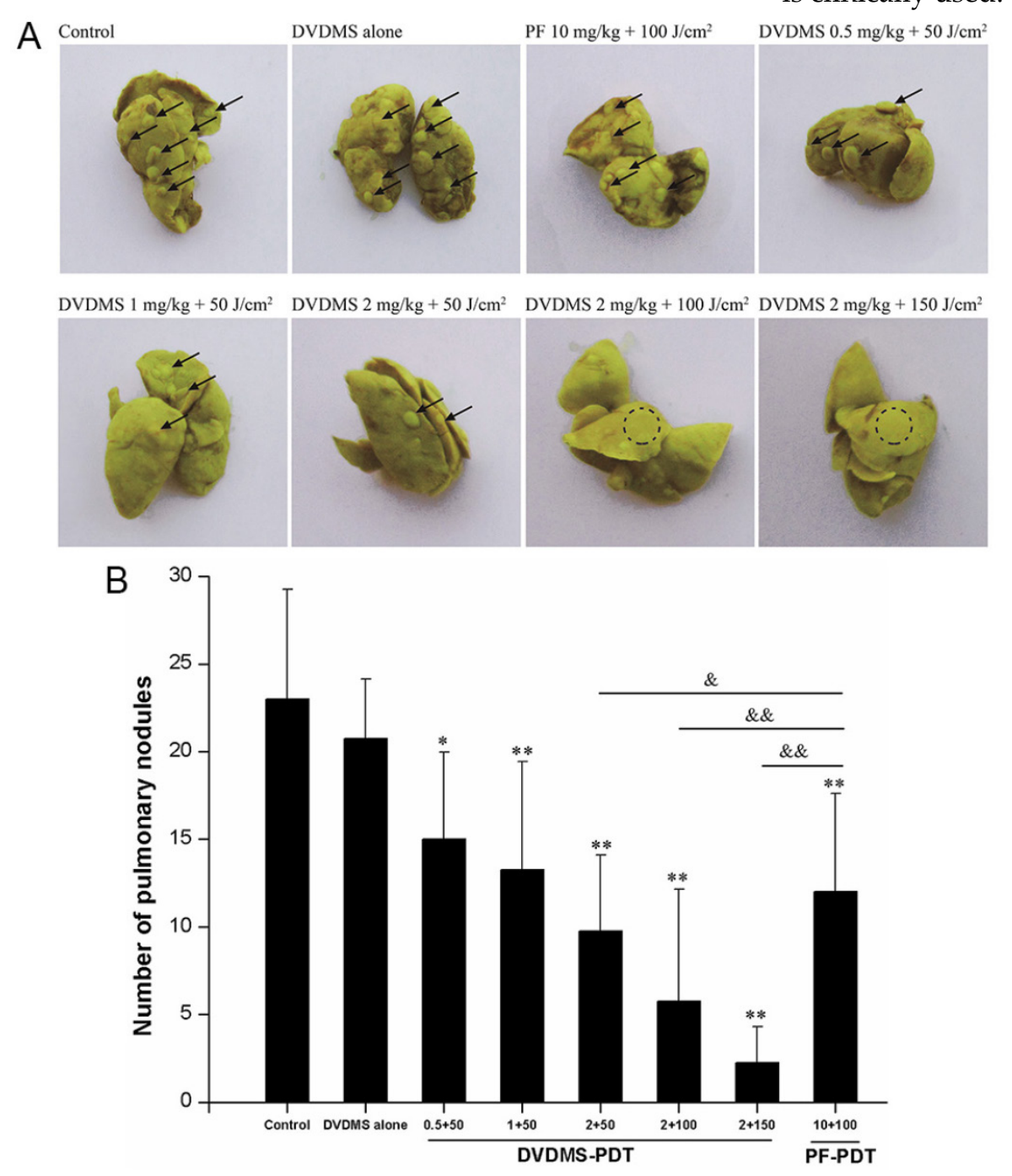

\section{Evaluation of side effects using DVDMS-PDT}

One of the main concerns in developing photosensitizers is the unknown toxicity to organs other than tumors. Therefore, we examined the potential in vivo toxicity of DVDMS-PDT. We did not detect any overt signs of toxic side effects or changes in body weight (Fig. 10A) with DVDMS-PDT at $2 \mathrm{mg} / \mathrm{kg}$, suggesting that both DVDMS and PF had no adverse effect on the growth of mice. Furthermore, we harvested the major organs including the heart, liver, spleen, and kidney. We were unable to detect any organ damage using H\&E staining (Fig. 10B). In addition, we measured acute hepatic damage induced by DVDMS by measuring the levels of GOT and GPT. The results indicated that the levels of GOT (Fig. 10C, a) and GPT (Fig. 10C, b) reverted to normal levels after $96 \mathrm{~h}$. Together, these data suggest there are no observable side effects of DVDMS at the treatment dose and that the treatment is relatively safe to administer. However, the present safety evaluation of DVDMS is somewhat limited and should be expanded by a series of rigorous assessments before DVDMS is clinically used.

Fig. 8 DVDMS-PDT inhibits lung metastasis in vivo. $\mathrm{A}$ : Photos of lungs after soaking in Bouin's solution showing spontaneous pulmonary breast cancer metastases (black arrows and dotted circle). B: The pulmonary nodules were manually counted and the average numbers were calculated in different groups. $* p<0.05, * * p<0.01$ versus control and DVDMS alone, \& $p<0.05$, \&\& $p<0.01$ DVDMS-PDT groups versus $10 \mathrm{mg} / \mathrm{kg} \mathrm{PF}+100 \mathrm{~J} / \mathrm{cm}^{2}$ light group. 

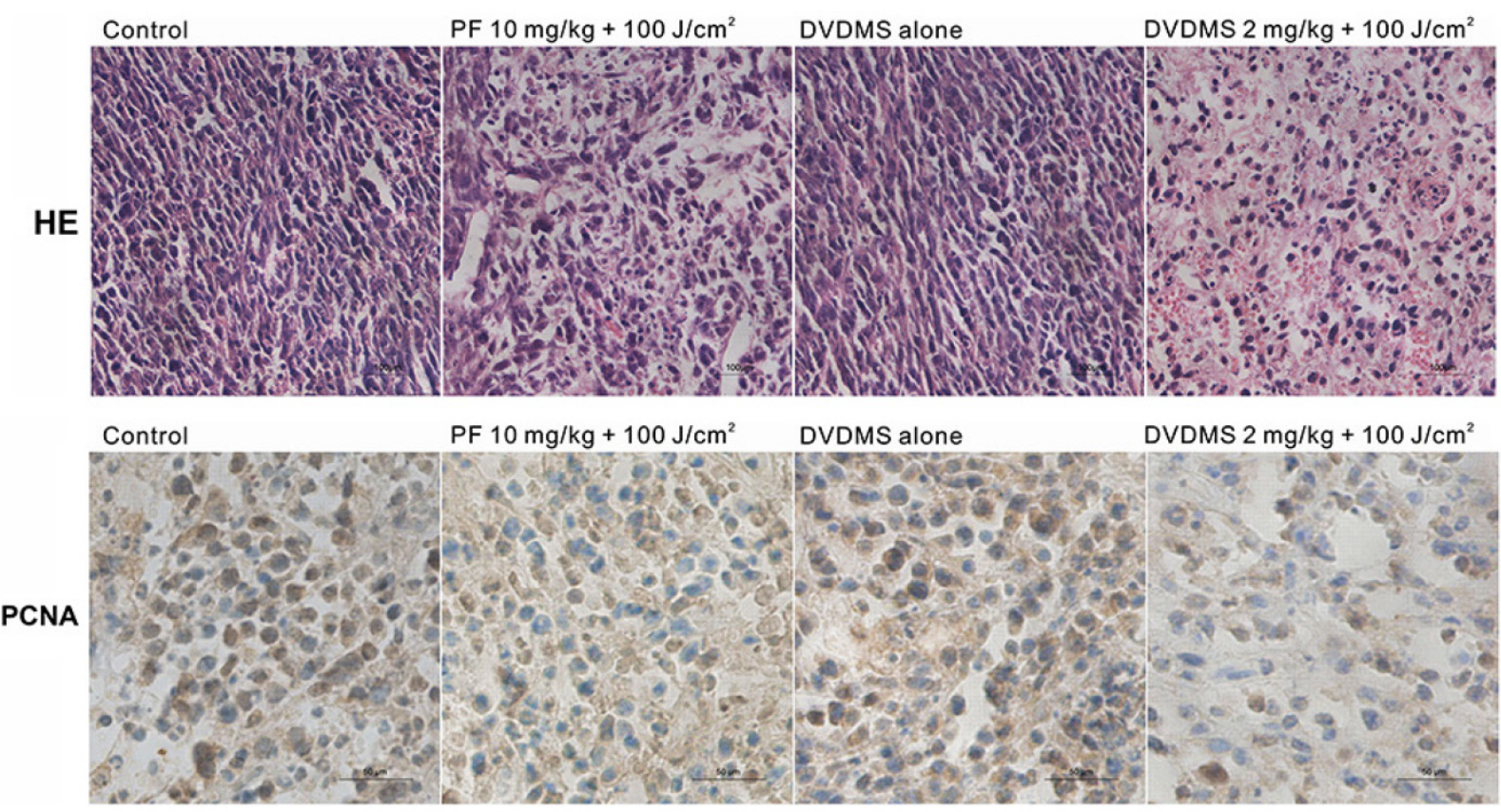

Fig. 9 Microscopic observation of tumor sections after different treatment. Tumor sections were stained with hematoxylin and eosin (HE) (Upper) or subjected to immunohistochemistry detection for PCNA (lower). Images were captured under a light microscope ( $\times 400$ magnification).
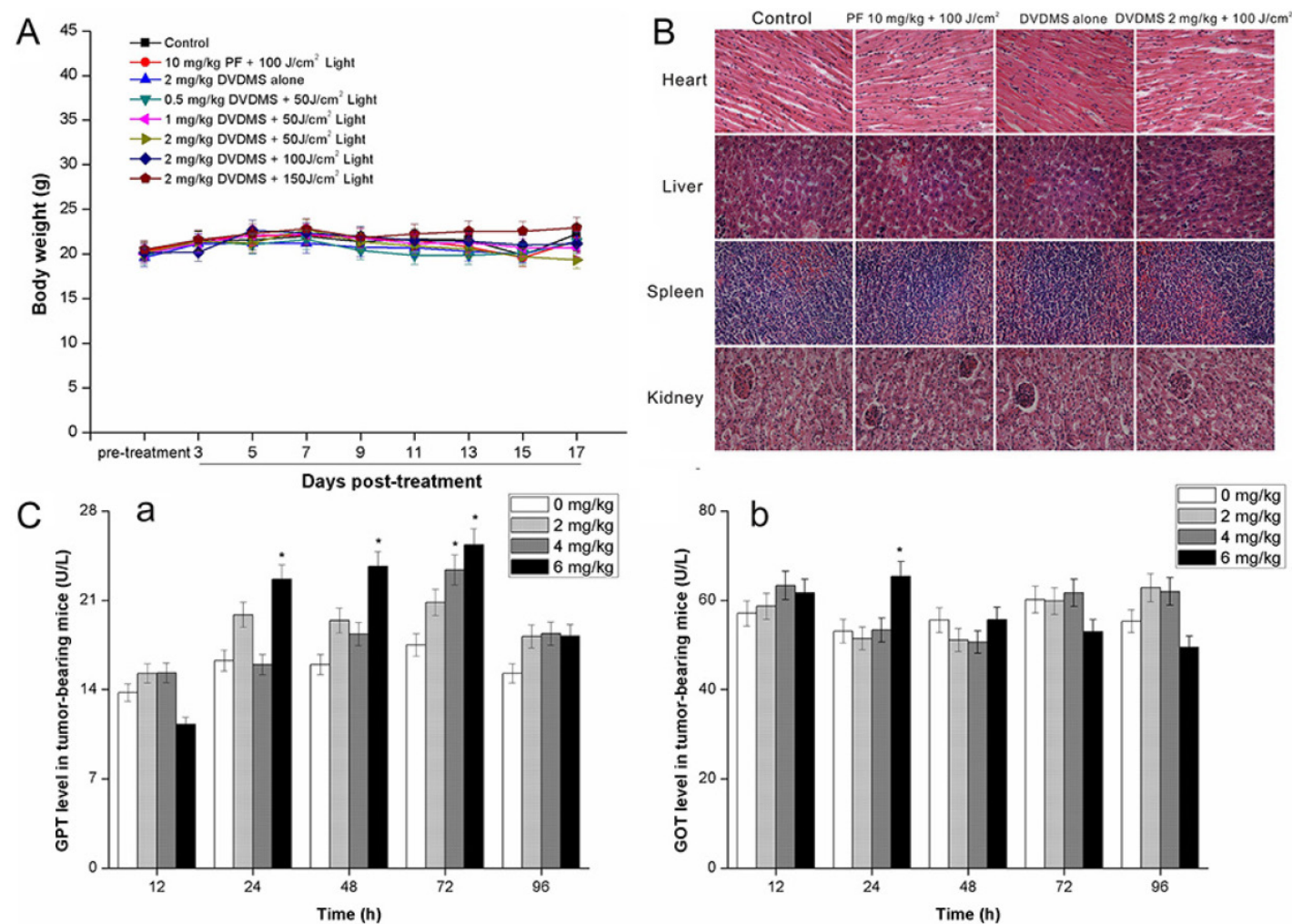

Fig. 10 Evaluation of side effects using DVDMS-PDT. A: A plot of body weight versus the number of days post different treatments. Data were shown as mean $\pm S D$ from eight mice in each group. B: Effect of different treatments on the structural changes of major organs in 4T1-bearing mice. Major organ sections were stained with hematoxylin and eosin (H\&E). Histopathological changes were observed under a light microscope ( $\times 400$ magnification). C: The GPT (a) and GOT (b) level in different groups at different time points post DVDMS administration. ${ }^{*} p<0.05$ versus $0 \mathrm{mg} / \mathrm{kg}$ DVDMS group.

\section{Discussion}

Effective treatments are urgently needed as breast cancer therapies because of its poor prognosis.
PDT, a minimally invasive therapeutic approach, has been widely used in the treatment of various tumors since the 1990s. Its efficacy as a therapeutic strategy is well documented [12, 26, 27]. Photosensitizers are a key component in the process of PDT development. 
However, only PF has been widely approved and used by many countries in clinical cancer therapies. The development of new photosensitizers will extend the number of choices for treating cancers.

DVDMS is a novel photosensitizer, and Professor Qicheng Fang has demonstrated that DVDMS has $98.5 \%$ chemical purity, is highly soluble in water, and results in relatively short-time skin sensitivity [14]. Previously, DVDMS was found to generate high singlet oxygen production and selectively accumulate in tumor cells and tumor tissue, both of which are necessary for targeted therapy [28-30]. Furthermore, DVDMS-mediated PDT was preliminarily confirmed to exhibit stronger tumoricidal activity than Photofrin-PDT in S180, H460- tumor bearing mice [15]. These characteristics indicated that DVDMS was a strong candidate for use as a photosensitizer in PDT.

The use of DVDMS-PDT has not been examined in the context of breast cancer models, and nothing is known about its potential effects on metastasis. Here, we assessed the effects of DVDMS mediated PDT in breast cancer, including anti-proliferation and anti-metastasis activity in vitro and in vivo, using the highly metastatic cell line 4T1.

The spectroscopic properties of photosensitizers are critical for PDT and photodynamic diagnosis because the spectroscopic properties are the basis for choosing the light wavelength for exposure [4]. In addition, changes in spectroscopic properties can indicate aggregation or other changes in the photosensitizers. Therefore, we measured absorption spectra and fluorescence spectra for DVDMS. We also examined the effects of $\mathrm{pH}$ and ionic strength of the buffer solution. The results suggest that the absorption spectra and fluorescence emission spectra of DVDMS were similar to those of other porphyrins, and DVDMS was present mainly in a monomeric form (Fig. 2A). In addition, the spectra also indicate DVDMS is highly stable in solution. Pandy et al synthesized porphyrin dimers and trimers in their previous study; however, these compounds were found to be unstable at RT either as solids or in solution [31]. These results suggest that DVDMS is more stable than other porphyrin dimers and trimers.

DVDMS is a derivative of PF, and the spectroscopic data for DVDMS indicate that it has the same Q-band absorption as PF at approximately $630 \mathrm{~nm}$, which may limit penetration into deep tumor tissues. $\mathrm{Li}$ et al developed polyethylene glycol (PEG)functionalized iron oxide nanoclusters (IONCs) to load chlorin e6 (Ce6). The obtained IONC-PEG-Ce6 exhibits a red-shifted absorption peak, and thus can be excited using near-infrared light. The Ce6 absorbance peak at $650 \mathrm{~nm}$ was shifted to $700 \mathrm{~nm}$, which is advantageous for deeper tissue penetration in optical imaging and phototherapy [32]. Perhaps DVDMS has the same potential to be modified such that it can be excited by near-infrared light.

A photosensitizer with high photosensitivity is essential for clinical PDT [26, 27]. In this study, we performed both in vitro and in vivo experiments to evaluate the efficiency of DVDMS in PDT. We used a MTT assay and colony formation assay to corroborate the photodynamic effects of DVDMS on $4 \mathrm{~T} 1$ cells. The MTT assay indicated that tumor cell survival was significantly decreased after DVDMS-PDT treatment, and this effect exhibited light-dose dependence (Fig. 3A). Under the same PDT conditions, DVDMS-PDT exhibited a higher efficacy than PF-PDT in inhibiting growth of 4T1 cells. Colony formation significantly decreased after PDT treatment, and this effect was more severe in the DVDMS-PDT group than in the PF-PDT group. In addition, several studies have indicated that PDT induced cytotoxicity is associated with the generation of ROS [26, 27, 33, 34]. Excessive ROS can damage lipids, proteins, and DNA as well as cause mitochondrial dysfunction, deregulate ion balance, and cause loss of membrane integrity [35]. Here, we detected a significant increase in ROS $2 \mathrm{~h}$ after DVDMS-PDT treatment. In addition, the amount of ROS produced occurred in a light dose-dependent manner (Fig. 4A, 4B). The crucial role of ROS in PDT-induced cell death was confirmed using the application of the ROS scavenger NAC. Cell survival was significantly increased in the presence of NAC in the DVDMS-PDT groups (Fig. 4C), suggesting that an oxidative stress mechanism was involved in the 4T1 cell response to PDT.

For many cancer patients, removal of the primary tumor is curative; however, if metastatic lesions exist and are not responsive to treatment, survival is limited $[2,3]$. Therefore, inhibiting metastasis is key to improving patient prognosis. We investigated the effects of DVDMS-PDT on metastasis. To begin, we assessed the effects of DVDMS-PDT on cell migration. DVDMS-PDT inhibited the migration and invasion capacity of 4T1 cells in a dose-dependent manner (Fig. 5A and B). DVDMS-PDT inhibited cell migration to a greater extent than PF-PDT.

Reports have indicated that microvilli on the cell surface are closely associated with cell motility [22]. The microvilli of tumor cells play a key role in response to environmental changes and in their adhesion, migration, and metastatic potential. In addition, they mediate the exchange of materials with the external environment to facilitate the malignant proliferation and attachment of tumor cells [22]. Here, we observed the disappearance of microvilli on the cell surface with DVDMS-PDT treatment, in a dose-dependent manner (Fig. 5C). This suggests that 
loss of microvilli might be one of the mechanisms by which cell migration is altered after PDT treatment. Moreover, the F-actin cytoskeleton is a structural network that is essential to multiple biological functions, including cell contraction, cell motility, and vesicle trafficking $[36,37]$. Functional and structural changes in cytoskeletal components, such as intermediate filaments, may affect the dynamics of cell adhesion $[23,38,39]$. Previous studies have suggested that PDT may lead to impairments of the cell surface or cytoskeleton [40-42]. We observed a disordered arrangement of F-actin in the PDT groups in a dose-dependent manner (Fig. 5D), suggesting PDT alters the F-actin cytoskeleton. These results also suggest that the collapse of F-actin network might be involved in the effects seen on cell migration and invasion.

The time interval between drug administration and light irradiation is an important factor influencing PDT efficacy [43, 44]. Therefore, we assessed the pharmacokinetics of DVDMS in 4T1 tumor-bearing mice to determine the appropriate light treatment time. The results suggest that in order to have a therapeutic effect on tumors (high concentration in tumors) and to minimize side effects on healthy tissues (low concentration in surrounding healthy tissues), DVDMS should be treated with light irradiation $24 \mathrm{~h}$ post administration.

PDT-mediated effects on tumor growth, volume, and weight as well as the mean survival times in response to PDT treatment were assessed. In additions, lung metastases were analyzed as 4T1 tumors have been reported to spontaneously metastasize to the lung $[45,46]$. Our results indicated that PDT using DVDMS significantly prolonged the survival of $4 \mathrm{~T} 1$ tumor-bearing mice (Fig. 7D) and inhibited tumor growth (Fig. 7A-C) and metastasis (Fig. 8) in a drug concentration and light dose-dependent manner. When light treatment of $150 \mathrm{~J} / \mathrm{cm}^{2}$ was combined with $2 \mathrm{mg} / \mathrm{kg}$ DVDMS, the tumors were hardly detectable at 6 days post treatment, while after 18 days, the tumors in this group were significantly smaller than control groups but could be detected (Supplementary Material: Figure S1). When using PDT with Photofrin ${ }^{\circledR}$, it is advised to administer a second laser light treatment as early as $96 \mathrm{~h}$ or as late as $120 \mathrm{~h}$ after the initial injection. Therefore, it is possible that multiple light exposures using DVDMS might enhance treatment efficacy. We evaluated the effects of PDT treatment on cell proliferation by detecting the expression level of PCNA, a representative marker of proliferation, which was significantly down regulated by PDT treatment (Fig. 9). Together, these in vivo results suggest that PDT-DVDMS is advantageous compared with PDT-PF as the therapeutic response using $2 \mathrm{mg} / \mathrm{kg}$ DVDMS was stronger than $10 \mathrm{mg} / \mathrm{kg}$ $\mathrm{PF}$ with the same light irradiation. These data were in agreement with our in vitro findings.

Fluorescence-guided surgery is an advantageous technique for the treatment of tumors due to its ability to precisely guide intraoperative positioning [47]. Given that porphyrins are auto-fluorescent, PDT is appealing as a therapeutic strategy since the same chemical compound can act as both the imaging and therapeutic agent [5]. DVDMS was found to exhibit a higher fluorescence intensity than many other photosensitizers, including hematoporphyrin, protoporphyrin IX, and PF [28]. This suggests that tumors marked with DVDMS could be demarcated easily with reduced background noise, which may be advantageous in fluorescence imaging-guided PDT compared with other photosensitizers. Recently, nanoparticles have been recognized as potential PDT drug carrier systems because of their high stability, high carrier capacity, high tumor delivery, ability to carry both hydrophobic and hydrophilic agents, and their ability to be administered using multiple methods $[48,49]$. Many photosensitizers have been successfully modified into nanoplatforms, including 5-ALA, Ce6, HPPH, and PpIX [50-54], which improved their PDT efficiency and tumor targeting. We predict that tumor targeting, imaging, and selective therapy could be further improved if DVDMS is packed in an optimized nanoplatform.

Finally, there were no detectable side effects using PDT-DVDMS at the therapeutic dose according to preliminary safety analysis, and the treatment is relatively safe to administer. However, our evaluation of DVDMS-PDT safety was somewhat limited. It will be necessary to perform a rigorous safety assessment before this treatment is used in clinical cancer therapy.

\section{Conclusions}

In summary, we performed both in vitro and in vivo assessments of the photodynamic effects of DVDMS on 4T1 breast cancer. The results suggest that DVDMS was more effective in inhibiting cancer growth and metastasis than PF, a conventional clinically used photosensitizer. Combined with the previously reported advantages [16, 28, 29, 30], we propose that DVDMS is a promising sensitizer that warrants further development for PDT as well as other sensitizing drug-based therapies.

\section{Supplementary material}

Figure S1-S2. http:/ / www.thno.org/v05p0772s1.pdf

\section{Acknowledgements}

This research was supported by the National Natural Science Foundation of China (No. 81472846) 
and the Fundamental Research Funds for the Central Universities (GK201502009). We thank Qicheng Fang and Haiyan $\mathrm{Wu}$ (Chinese Academy of Medical Sciences) for their help with our work.

\section{Conflict of Interest}

The authors have declared that no competing interest exists.

\section{References}

1. Jemal A, Bray F, Center MM, Ferlay J, Ward E, Forman D. Global cancer statistics. CA Cancer J Clin. 2011; 61: 69-90.

2. O'Shaughnessy J. Extending survival with chemotherapy in metastatic breast cancer. Oncologist. 2005; 10: 20-9.

3. Irvin W Jr, Muss HB, Mayer DK. Symptom management in metastatic breast cancer. Oncologist. 2011; 16: 1203-14

4. Dougherty TJ, Gomer CJ, Henderson BW, Jori G, Kessel D, Korbelik M, et al. Photodynamic therapy. J Natl Cancer Inst. 1998; 90: 889-905.

5. Josefsen LB, Boyle RW. Unique diagnostic and therapeutic roles of porphyrins and phthalocyanines in photodynamic therapy, imaging and theranostics. Theranostics. 2012; 2: 916-66.

6. James NS, Ohulchanskyy TY, Chen Y, Joshi P, Zheng X,Pandey RK,et al. Comparative tumor imaging and PDT Efficacy of HPPH conjugated in the mono- and di-forms to various polymethine cyanine dyes: part - 2. Theranostics. 2013; 3: 703-18.

7. Cai XJ, Li WM, Zhang LY, Wang XW, Luo RC, Li LB, Photodynamic therapy for intractable bronchial lung cancer. Photodiagnosis Photodyn Ther. 2013; 10: 672-6.

8. Choi MC, Jung SG, Park H, Lee SY, Lee C, Hwang YY, et al. Photodynamic therapy for management of cervical intraepithelial neoplasia II and III in young patients and obstetric outcomes. Lasers Surg Med. 2013; 45: 564-72.

9. Filonenko EV, Sokolov VV, Chissov VI, Lukyanets EA, Vorozhtsov GN. Photodynamic therapy of early esophageal cancer. Photodiagnosis Photodyn Ther. 2008; 5 : $187-90$.

10. Neuhaus J, Schastak S, Berndt M, Walther J, Dietel A, Sieger N, et al. Photodynamic therapy of bladder cancer. Urologe A. 2013; 52: 1225-32

11. Story W, Sultan AA, Bottini G, Vaz F, Lee G, Hopper C. Strategies of airway management for head and neck photo-dynamic therapy. Lasers Surg Med. 2013; 45. 370-6.

12. Yano S, Hirohara S, Obata M, Hagiya Y, Ogura S, Ikeda A, et al. Current states and future views in photodynamic therapy. J Photoch Photobio C. 2011; 12: 46-67.

13. Zhang Y, Lovell JF. Porphyrins as theranostic agents from prehistoric to modern times. Theranostics. 2012; 2: 905-15.

14. Fang $Q$, Yang D. A porphyrin dimer sodium salt combined with the ether bond and its manufacturing method. [P]. 2012; ZL200910179116.5. China.

15. Jiang Z, Shi R, Li C, Wang A. Inhibitory effects of DVDMS-2- based-photodynamic therapy on the growth of tumor in vitro and in vivo. Teratog Carcinog Mutagen. 2013; 25: $163-7$.

16. Hu J, Wang $X$, Liu $Q$, Zhang $K$, Xiong $W, X u$ C, et al. Antitumor Effect of Sinoporphyrin sodium mediated Photodynamic Therapy on Human Esophageal Cancer Eca-109 cells. Photochem Photobiol. 2014; 90: 1404-12.

17. Li Y, Wang P, Zhao P, Zhu S, Wang X, Liu Q. Apoptosis induced by sonodynamic treatment by protoporphyrin IX on MDA-MB-231 cells. Ultrasonics. 2012; 52: 490-6.

18. Kessel D, Reiners J Jr. Light-Activated Pharmaceuticals: Mechanisms and Detection. Isr J Chem. 2012; 52: 674-80.

19. Wang B, Wang JH, Liu Q, Huang H, Chen M, Li K. Rose-bengal-conjugated gold nanorods for in vivo photodynamic and photochermal oral cancer therapies. Biomaterials. 2014; 35: 1951-66.

20. Rubio N, Verrax J, Dewaele M, Verfaillie T, Johansen T, Piette J. p38 (MAPK)-regulated induction of p62 and NBR1 after photodynamic therapy promotes autophagic clearance of ubiquitin aggregates and reduces reactive oxygen species levels by supporting Nrf2-antioxidant signaling. Free Radic Biol Med. 2014; 67: 292-303.

21. Kim $\mathrm{CH}$, Chung $\mathrm{CW}$, Choi $\mathrm{KH}$, Yoo JJ, Kim do H, Jeong YI, et al. Effect of 5 -aminolevulinic acid-based photodynamic therapy via reactive oxygen species in human cholangiocarcinoma cells. Int J Nanomedicine. 2011; 6: 1357-63.

22. Hrazdira I, Skorpíková J, Dolníková M. Ultrasonically induced alterations of cultured tumour cells. Eur J Ultrasound. 1998; 8: 43-9.

23. McInroy L, Määttä A. Down-regulation of vimentin expression inhibits carcinoma cell migration and adhesion. Biochem Biophys Res Commun. 2007; 360: 109-14.

24. Yamada KM, Geiger B. Molecular interactions in cell adhesion complexes. Curr Opin Cell Biol. 1997; 9: 76-85.

25. Dillehay KL, Seibel WL, Zhao D, Lu S, Dong Z. Target validation and structure-activity analysis of a series of novel PCNA inhibitors. Pharmacol Res Perspect. 2015; 3: e00115.

26. Allison RR, Moghissi K, Photodynamic Therapy (PDT): PDT Mechanisms. Clin Endosc. 2013; 46: 24-9.

27. Kohl E, Karrer S. New developments in photodynamic therapy. Hautarzt. 2013; 64: 363-9.

28. Wang H, Wang X, Zhang S, Wang P, Zhang K, Liu Q. Sinoporphyrin sodium, a novel sensitizer, triggers mitochondrial-dependent apoptosis in ECA-109 cells via production of reactive oxygen species. Int J Nanomedicine. 2014; 25: 3077-90.

29. Hu J, Wang X, Zhang K, Wang P, Su X, Li Y, et al. Sinoporphyrin sodium: a novel sensitizer in sonodynamic therapy. Anticancer Drugs. 2014; $25: 174-82$

30. Li C, Zhang K, Wang P, Hu J, Liu Q, Wang X. Sonodynamic antitumor effect of a novel sonosensitizer on S180 solid tumor. Biopharm Drug Dispos. 2014; 35: 50-59.
31. Pandey RK, Dougherty TJ. Syntheses and photosensitizing activity of porphyrins joined with ester linkages. Cancer Res. 1989; 49: 2042-7.

32. Li Z, Wang C, Cheng L, Gong H, Yin S, Gong Q, et al. PEG-functionalized iron oxide nanoclusters loaded with chlorin e6 for targeted, NIR light induced, photodynamic therapy. Biomaterials. 2013; 34: 9160-70.

33. Tomankova K, Kolarova H, Bajgar R, Jirova D, Kejlova K, Mosinger J. Study of the photodynamic effect on the A549 cell line by atomic force microscopy and the influence of green tea extract on the production of reactive oxygen species. Ann N Y Acad Sci. 2009; 1171: 549-58.

34. Malkov A, Ivanov AI, Popova I, Mukhtarov M, Gubkina O, Waseem T, et al. Reactive oxygen species initiate a metabolic collapse in hippocampal slices: potential trigger of cortical spreading depression. J Cereb Blood Flow Metab. 2014; 16.

35. Khaitlina SY. Functional specificity of actin isoforms. Int Rev Cytol. 2001; 202: 35-98.

36. Cooper JA. The role of actin polymerization in cell motility. Annu Rev Physiol. 1991; 53: 585-605

37. Furukawa S, Soeda S, Kiko Y, Suzuki O, Hashimoto Y, Watanabe T, et al. MCP-1 promotes invasion and adhesion of human ovarian cancer cells. Anticancer Res. 2013; 33: 4785-90

38. Hirata H, Sokabe M, Lim CT. Molecular Mechanisms Underlying the Force-Dependent Regulation of Actin-to-ECM Linkage at the Focal Adhesions. Prog Mol Biol Transl Sci. 2014; 126: 135-54

39. Uzdensky A, Kristiansen B, Moan J, Juzeniene A. Dynamics of signaling, cytoskeleton and cell cycle regulation proteins in glioblastoma cells after sub-lethal photodynamic treatment: antibody microarray study. Biochim Biophys Acta. 2012; 1820: 795-803.

40. Ferreira SD, Tedesco AC, Sousa G, Zângaro RA, Silva NS, Pacheco MT, et al. Analysis of mitochondria, endoplasmic reticulum and actin filaments after PDT with AlPcS(4). Lasers Med Sci. 2004; 18: 207-212.

41. Tsai JC, Wu CL, Chien HF, Chen CT. Reorganization of cytoskeleton induced by 5 -aminolevulinic acid-mediated photodynamic therapy and its correlation with mitochondrial dysfunction. Lasers Surg Med. 2005; 36: 398-408

42. Gao Z, Zheng J, Yang B, Wang Z, Fan H, Lv Y, et al. Sonodynamic therapy inhibits angiogenesis and tumor growth in a xenograft mouse model. Cancer Lett. 2013; 335: 93-9.

43. Shi H, Liu Q, Qin X, Wang P, Wang X. Pharmacokinetic study of a novel sonosensitizer chlorin-e6 and its sonodynamic anti-cancer activity in hepatoma-22 tumor-bearing mice. Biopharm Drug Dispos. 2011; 32: 319-32.

44. Aslakson CJ, Miller FR. Selective events in the metastatic process defined by analysis of the sequential dissemination of subpopulations of a mouse mammary tumor. Cancer Res. 1992; 52: 1399-405.

45. Tao K, Fang M, Alroy J, Sahagian GG. Imagable 4T1 model for the study of late stage breast cancer. BMC Cancer. 2008; 8: 228.

46. Chi C, Du Y, Ye J, Kou D, Qiu J,Chen X,et al. Intraoperative Imaging-Guided Cancer Surgery: From Current Fluorescence Molecular Imaging Methods to Future Multi-Modality Imaging Technology. Theranostics. 2014; 4: 1072-1084.

47. Gelperina S, Kisich K, Iseman MD, Heifets L. The potential advantages of nanoparticle drug delivery systems in chemotherapy of tuberculosis. Am J Respir Crit Care Med. 2005; 172: 1487-90.

48. Menon JU, Jadeja P, Tambe P, Vu K, Yuan B, Nguyen KT. Nanomaterials for photo-based diagnostic and therapeutic applications. Theranostics. 2013; 3: 152-66.

49. Shi L, Wang $\mathrm{X}$, Zhao $\mathrm{F}$, Luan $\mathrm{H}$, Tu Q, Huang $\mathrm{Z}$, et al. In vitro evaluation of 5-aminolevulinic acid (ALA) loaded PLGA nanoparticles. Int J Nanomedicine. 2013; 8. 2669-76.

50. Jeong H, Huh M, Lee SJ, Koo H, Kwon IC, Jeong SY, et al. Photosensitizer-conjugated human serum albumin nanoparticles for effective photodynamic therapy. Theranostics. 2011; 1: 230-9.

51. Huang P, Li Z, Lin J, Yang D, Gao G, Xu C, et al. Photosensitizer-conjugated magnetic nanoparticles for in vivo simultaneous magnetofluorescent imaging and targeting therapy. Biomaterials. 2011; 32: 3447-58

52. Wang S, Kim G, Lee YE, Hah HJ, Ethirajan M, Pandey RK, et al. Multifunctional biodegradable polyacrylamide nanocarriers for cancer theranostics--a "see and treat" strategy. ACS Nano. 2012; 6: 6843-51.

53. Rong P, Yang K, Srivastan A, Kiesewetter DO, Yue X, Wang F, et al. Photosensitizer loaded nano-graphene for multimodality imaging guided tumor photodynamic therapy. Theranostics. 2014; 4: 229-39.

54. Srivatsan A, Jenkins SV, Jeon M, Wu Z, Kim C, Chen J, et al. Gold nanocage-photosensitizer conjugates for dual-modal image-guided enhanced photodynamic therapy. Theranostics. 2014; 4: 163-74. 